\title{
Relationship between macrobenthos and abiotic characteristics of river Alaknanda in a stretch from Chamoli to Devprayag in Garhwal Himalayan region of Uttarakhand, India
}

\author{
Garima Tomar* \\ Environmental Hydrology Division, National Institute of Hydrology, Roorkee (Uttarakhand), \\ India

\section{S. Malik} \\ Department of Zoology and Environmental Sciences, Gurukula Kangri Vishwavidyalaya, \\ Haridwar-24940 (Uttarakhand), India \\ C. K. Jain \\ Environmental Hydrology Division, National Institute of Hydrology, Roorkee (Uttarakhand), \\ India \\ ${ }^{*}$ Corresponding author. Email: rs.garima@gkv.ac.in
}

\section{Article Info}

https://doi.org/10.31018/

jans.v13i3.2721

Received: May 16, 2021

Revised: September 9, 2021

Accepted: September 14, 2021

\section{How to Cite}

Tomar, G. et al. (2021). Relationship between macrobenthos and abiotic characteristics of river Alaknanda in a stretch from Chamoli to Devprayag in Garhwal Himalayan region of Uttarakhand, India. Journal of Applied and Natural Science, 13(3), 1135 - 1142. https://doi.org/10.31018/jans.v13i3.2721

\begin{abstract}
Macrobenthos is the best water quality indicator for ecosystem health assessment. The present study aimed to examine the interrelationship between macrobenthos and different water quality parameters of the river Alaknanda at Garhwal Himalaya. Four demarcated sampling zones viz. zone-A (Chamoli to Nandprayag), zone-B (Karanprayag to Rudraprayag), zone-C (Rudraprayag to Srinagar) and zone-D (Srinagar to Devprayag) were taken from its approximately $170 \mathrm{~km}$ long stretch during 2016-2018. River water characteristics were analyzed for the important parameters viz. substratum, water temperature (WT), water velocity, $\mathrm{pH}$, electrical conductivity (EC), total dissolved solids (TDS), calcium (Ca), and magnesium (Mg) using standard methods. The results indicated that the river water velocity was the highest $1.02 \mathrm{~m} / \mathrm{s}$ at zone-C, TDS of $114.19 \mathrm{mgl}^{-1}$ was maximum at zone-A ; and $\mathrm{Ca}$ and $\mathrm{Mg}$ were recorded highest $23.17 \mathrm{mgl}^{-1}$ and $5.44 \mathrm{mgl}^{-1}$ at zone-A and zone-B, respectively. All abiotic parameters $(\mathrm{pH}, \mathrm{EC}, \mathrm{TDS}, \mathrm{DO}, \mathrm{Ca}$ and $\mathrm{Mg})$ were recorded to be below BIS/WHO limits. A total of 27 macrobenthos taxa belonging to the five orders such as Coleoptera $\left(6 \mathrm{ind} . / \mathrm{m}^{2}\right)$, Diptera $\left(5 \mathrm{ind} . / \mathrm{m}^{2}\right)$, Ephemeroptera $\left(8 \mathrm{ind} . / \mathrm{m}^{2}\right)$, Hemiptera $(4 \mathrm{ind} . /$ $\mathrm{m}^{2}$ ), and Odonata $\left(4\right.$ ind. $\left./ \mathrm{m}^{2}\right)$ were recorded. Macrobenthos represented an important relationship between the water current and water temperature. The lowest number was reported at zone-C due to the river's high water velocity $(1.02 \mathrm{~m} / \mathrm{s})$. The changes like biota loss, presence of some pollution indicator species (Cloeon sp., Bateis sp., Emphemera sp.) at zone-C, in sediment structure of habitat were due to the anthropogenic activities on the riverbank of different zones. The study will help in the conservation of macrobenthos diversity of the river Alaknanda.
\end{abstract}

Keywords: Abiotic characteristics, Alaknanda river, Anthropogenic factors, Biotic characteristics, Macrobenthos

\section{INTRODUCTION}

Macroinvertebrates are bottom dwellers, act as the best water quality indicator for a freshwater ecosystem. The macro-benthos fauna uses as the best bioassessment measure (Kumar et al., 2017). Benthic aquatic macroinvertebrates are sensitive indicators of environmental changes in streams because they express long-term water and habitat quality changes rather than instantaneous conditions (Johnson et al., 2017). Macro-benthos play an important role in food web. These are the favourite food for fish and waterfowls. They transfer energy from trophic level one to trophic level two in the form of food (Sharma and Rawat, 2009). Macrobenthos are small aquatic fauna which is quite difficult to identify. These aquatic organisms are smaller in size, found in all over the world's aquatic ecosystem. Despite the fewer studies on macrobenthos, some species are lost due to habitat degradation, a few remain undiscovered (Singh, 1998). Aquatic biodiversity plays 
an important role in an aquatic ecosystem. The river water quality changes the species confirmation, abundance, and productivity of biotic components in a water ecosystem (Mishra et al., 2009).

The variety of aquatic habitats, such as leaf debris, rock surfaces, backwaters, plant surfaces, sediments, sands, logs, pebbles, and gravel, are present in the Garhwal region to aquatic biota. Benthic invertebrates observations are the best choice for monitoring any aquatic body (Hellawell, 1977). Aquatic biota copiously has been studied in Northern River and streams by various researchers (e.g., Malik et al., 2020; Rana et al., 2017; Singh et al., 2010; Kumar et al., 1998; Balodi and Koshal, 2015). Anthropogenic (a direct inlet of waste into the river, dam constructions, waste disposal etc.) and natural factors (flash floods, droughts etc.) are responsible for habitat degradation for aquatic fauna. A few researchers worked on benthic communities viz. on macroinvertebrates conservation of two Afrotropical streams (Arimoro et al., 2020), macrobenthos communities of Ghezel Ozan river in Iran (Aazami et al., 2019), on biomonitoring index of pollution assessment by using macroinvertebrates in Tropical African regions (Elias et al., 2014), on Osumi, Devolli, Shkumbini rivers in Albania (Duka et al., 2017) and on the biotic index of macroinvertebrates of Lepenci river in Kosovo (Pajtim et al., 2019). Some studies accomplished by Indian scientists are on macroinvertebrates and water quality assessment of Mahanadi river (Ganguly et al., 2018), monitoring of benthic macroinvertebrates of Dodi Tal, Uttarakhand (Singh and Sharma, 2020) and longitudinal and temporal study of snowmelt stream of Jhelum river of Kashmir (Sabha et al., 2020), Kamboj and Kamboj, (2020) studied river mining affected areas of river Ganga at Haridwar. The aim of the present study was to evaluate the relationship status between physicochemical water quality characteristics and macrobenthos (microinvertebrates) of river Alaknanda in a stretch from Chamoli to Devprayag in Garhwal Himalayan region of Uttarakhand.

\section{MATERIALS AND METHODS}

\section{Study area}

Alaknanda river is originating in the state of Uttarakhand, India, from the confluence of Satopanth and Bhagirathi kharak glaciers at an elevation of 3880 $\mathrm{m}$. It is one of the mainstream of the Ganges. The stretch was divided into four sampling zones. Study sites details are given in Table 1 and the complete stretch is represented in Fig. 1.

\section{Methodology}

The sampling was carried out on a monthly basis from September 2016- August 2018. Water samples were collected in sterilized polyethylene bottles in the early morning and afternoon hours (6:00 am to 02:00 pm). The physicochemical parameters like water velocity $(\mathrm{m} /$ $\mathrm{s})$, sediment structure $(\%)$, water temperature $\left({ }^{\circ} \mathrm{C}\right), \mathrm{pH}$, dissolved oxygen (DO) (mg/L) were performed on-site and the parameters like total dissolved solids (TDS) $(\mathrm{mg} / \mathrm{L})$, calcium $(\mathrm{Ca})(\mathrm{mg} / \mathrm{L})$ and magnesium $(\mathrm{Mg})(\mathrm{mg} /$

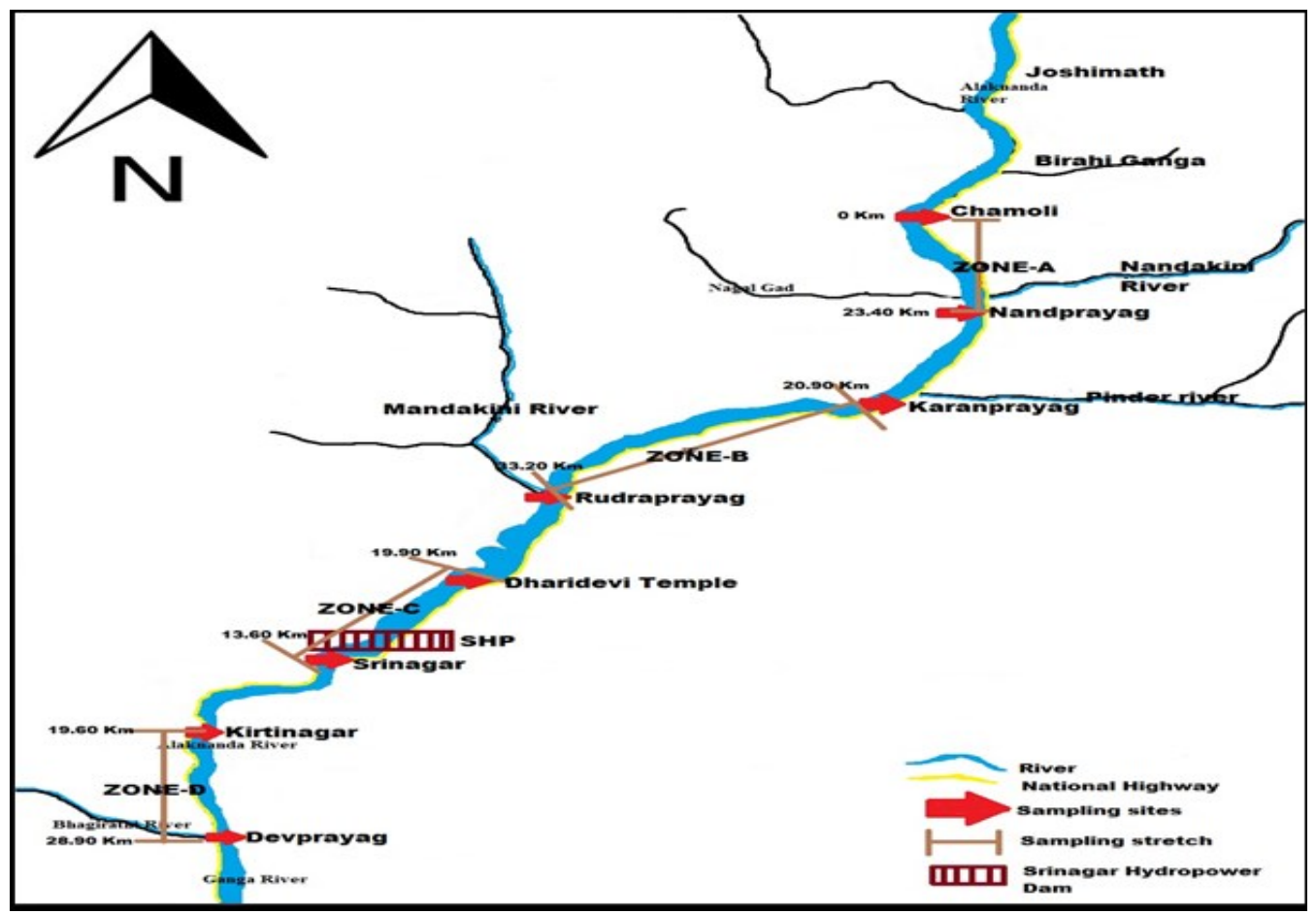

Fig. 1. Map showing sectional distribution of sampling zones in river Alaknanda 
Table 1. Geological characteristics of sampling sites of river Alaknanda

\begin{tabular}{llll}
\hline Sampling Zones & Sites & Geo-Coordinates & Stretch (km) \\
\hline \multirow{2}{*}{ Zone-A } & Chamoli & $30^{\circ} 17^{\prime} 37.48^{\prime \prime} \mathrm{N}, 79^{\circ} 33^{\prime} 37.24 " \mathrm{E}$ & 23 \\
& Nandprayag & $30^{\circ} 19^{\prime} 54^{\prime \prime} \mathrm{N}, 79^{\circ} 18^{\prime} 55^{\prime \prime} \mathrm{E}$ & 53 \\
Zone-B & Karnparyag & $30^{\circ} 15^{\prime} 30.85^{\prime \prime} \mathrm{N}, 79^{\circ} 13^{\prime} 05.98^{\prime \prime} \mathrm{E}$ & 32 \\
\hline \multirow{2}{*}{ Zone-C } & Rudraprayag & $30^{\circ} 17^{\prime} 15.05^{\prime \prime} \mathrm{N}, 78^{\circ} 358^{\prime} 42.2^{\prime \prime} \mathrm{E}$ & \\
\hline \multirow{2}{*}{ Zone-D } & Dharidevi & $30^{\circ} 15^{\prime} 26.1^{\prime \prime} \mathrm{N}, 78^{\circ} 52^{\prime} 41^{\prime \prime} \mathrm{E}$ & \\
& Srinagar & $30^{\circ} 17^{\prime} 04.03^{\prime \prime} \mathrm{N}, 79^{\circ} 58^{\prime} 52.42^{\prime \prime} \mathrm{E}$ & 47 \\
\hline
\end{tabular}

$\mathrm{L}$ ); and the biological analysis (macro benthos)were analyzed in the laboratory following the standard procedures of American Public Health Association (2012) and Edmondson (1957).

Substratum structure was analyzed by visual characterization technique and sediment substances were identified following the Wentworth scale (Wentworth 1922). Boulders, cobbles, pebbles, gravels and sand were measured on the basis of their grain diameter, i.e., $250-600 \mathrm{~mm}, 65-250 \mathrm{~mm}, 4-65 \mathrm{~mm}, 2-4 \mathrm{~mm}$ and 0 $-2 \mathrm{~mm}$ respectively. For the collection of macroinvertebrates, a manual Surber sampler with a sampling area of $10 \times 12$ inch of the river bed and a bolting silk net with a mesh size of $500 \mu \mathrm{m}$ was used, from $1 \mathrm{~m}$ deep to river surface. Macrobenthos species preserved in $10 \%$ formalin solution, were identified by using specific identification keys of Pennak (1953) and Day (1979). For data analysis, these abiotic parameters were correlated with macroinvertebrates. Different biodiversity indices like Shannon Wiener, Simpson, Evenness, Marglef, Dominance, Equitability, Fisher-alpha, Berger-parker and Menhinick were utilized appropriately to examine dominance, diversity and similarity between the species were observed in river Alaknanda (Shannon and Wiener 1949; Simpson 1949; Rosenzweig 1995). All these biotic indices were calculated by Paleontological statistics software (PAST).

\section{RESULTS AND DISCUSSION}

In the present study, macroinvertebrates were found belonging to 5 different Orders - Coleoptera, Diptera, Ephemeroptera, Hemiptera and Odonata at all zones during September 2016-Aug 2018. The observed values of physicochemical parameters analyzed at all sampling zones are given in Table 2 . The total number of identified macroinvertebrates species (33 ind $/ \mathrm{m}^{2}$ ) are shown in Table 3.

\section{Substratum features of river}

The substratum structure of a river is the principal component to provide suitable habitat for macrobenthic communities. The substrate boulders were recorded highest $7 \pm 8(\%)$ at zone-A and the lowest value $4 \pm 3$ (\%) was reported at zone-B. Cobbles were measured maximum $28 \pm 4(\%)$ at zone-A and minimum $7 \pm 3(\%)$ value was noted at zone-D. Pebbles were recorded highest $35 \pm 5(\%)$ at zone-A and the lowest value $8 \pm 2$ (\%) was recorded at zone-C. Gravels were measured maximum $27 \pm 6(\%)$ at zone-B, minimum value $6 \pm 1(\%)$ was recorded in winter at zone-D. In sampling locations, sand was measured $25 \pm 5(\%)$ at zone-C.

\section{Physicochemical characteristics of river water}

Water temperature was recorded in the range of $14.94 \pm 3.63\left({ }^{\circ} \mathrm{C}\right)$ to $16.4 \pm 4.01\left({ }^{0} \mathrm{C}\right)$, lowest to highest at zone-A to zone- $C$, respectively. River water velocity was maximum $1.02 \pm 0.21(\mathrm{~m} / \mathrm{s})$ at zone-C and the minimum water velocity $0.92 \pm 0.78(\mathrm{~m} / \mathrm{s})$ was found at zone -D. The $\mathrm{pH}$ was recorded maximum $7.98 \pm 0.22$ at zone $-A$, indicating the alkaline nature of river water suitable for biotic life. Electric conductivity ranged from $134.91 \pm 37.82(\mathrm{mS} / \mathrm{cm})$ to $178.43 \pm 32.52(\mathrm{mS} / \mathrm{cm})$ at zone-C to zone-A, total dissolved solids ranged from $70.94 \pm 14.98\left(\mathrm{mgl}^{-1}\right)$ at Zone A to $114.19 \pm 20.81\left(\mathrm{mgl}^{-1}\right)$ at Zone C. Dissolved oxygen varied from 9.30 \pm 0.55 $\left(\mathrm{mgl}^{-1}\right)$ to $9.60 \pm 0.55\left(\mathrm{mgl}^{-1}\right)$. Calcium concentration was reported in the range of $20.07 \pm 2.89\left(\mathrm{mgl}^{-1}\right)$ at zone-C to $23.17 \pm 2.82\left(\mathrm{mgl}^{-1}\right)$ at zone-A. Magnesium ranged form $4.11 \pm 1.58\left(\mathrm{mgl}^{-1}\right)$ at zone-C to $5.44 \pm 1.78\left(\mathrm{mgl}^{-1}\right)$ at zone-B (Table 2).

\section{Macroinvertebrate diversity of river Alaknanda}

In river Alaknanda, five different orders like Coleoptera (6 ind. $/ \mathrm{m}^{2}$ ), Diptera (5 ind. $/ \mathrm{m}^{2}$ ), Ephemeroptera (8 ind./ $\mathrm{m}^{2}$ ), Hemiptera (4 ind. $/ \mathrm{m}^{2}$ ) and Odonata (4 ind. $/ \mathrm{m}^{2}$ ) were found at all sites during the study period. The 
Table 2. Physicochemical characteristics of the sampling zones of river Alaknanda during 2016-2018

\begin{tabular}{|c|c|c|c|c|c|c|}
\hline \multirow[t]{2}{*}{ S. No. } & \multirow[t]{2}{*}{ Parameters } & \multirow[t]{2}{*}{$\begin{array}{l}\text { BIS/WHO criteria } \\
\text { limit }\end{array}$} & \multicolumn{4}{|c|}{ Sampling Zones } \\
\hline & & & Zone-A & Zone-B & Zone-C & Zone-D \\
\hline \multirow{5}{*}{1.} & Boulder (\%) & - & $27 \pm 8$ & $4 \pm 3$ & $5 \pm 3$ & $11 \pm 4$ \\
\hline & Cobbles (\%) & - & $28 \pm 4$ & $18 \pm 1$ & $15 \pm 4$ & $7 \pm 3$ \\
\hline & Pebbles (\%) & - & $35 \pm 5$ & $17 \pm 7$ & $8 \pm 2$ & $11 \pm 3$ \\
\hline & Gravel (\%) & - & $15 \pm 4$ & $27 \pm 6$ & $18 \pm 3$ & $6 \pm 1$ \\
\hline & Sand (\%) & - & $8 \pm 2$ & $10 \pm 3$ & $25 \pm 5$ & $6 \pm 2$ \\
\hline 2. & WT $\left({ }^{0} \mathrm{C}\right)$ & - & $14.94 \pm 3.63$ & $16.4 \pm 4.01$ & $17.34 \pm 4.16$ & $17.12 \pm 4.25$ \\
\hline 3. & Velocity $(\mathrm{m} / \mathrm{s})$ & & $0.98 \pm 0.17$ & $0.96 \pm 1.10$ & $1.02 \pm 0.21$ & $0.92 \pm 0.78$ \\
\hline 4. & $\mathrm{pH}$ & $6.5-8.5$ & $7.98 \pm 0.22$ & $7.98 \pm 0.14$ & $7.92 \pm 0.15$ & $7.97 \pm 0.17$ \\
\hline 5. & $\mathrm{EC}(\mathrm{mS} / \mathrm{cm})$ & $<1000 \mu \mathrm{S} / \mathrm{cm}$ & $178.43 \pm 32.52$ & $163.27 \pm 38.08$ & $134.91 \pm 37.82$ & $157.79 \pm 31.16$ \\
\hline 6. & TDS (mg/L) & $<500 \mathrm{mg} / \mathrm{L}$ & $114.19 \pm 20.81$ & $104.49 \pm 24.37$ & $70.94 \pm 14.98$ & $100.98 \pm 19.94$ \\
\hline 7. & D.O. (mg/L) & $\geq 5 \mathrm{mg} / \mathrm{L}$ & $9.60 \pm 0.55$ & $9.60 \pm 0.55$ & $9.30 \pm 0.55$ & $9.32 \pm 0.51$ \\
\hline 8. & $\mathrm{Ca}(\mathrm{mg} / \mathrm{L})$ & $<75 \mathrm{mg} / \mathrm{L}$ & $23.17 \pm 2.82$ & $22.74 \pm 2.35$ & $20.07 \pm 2.89$ & $22.29 \pm 1.99$ \\
\hline 9. & $\mathrm{Mg}(\mathrm{mg} / \mathrm{L})$ & $<30 \mathrm{mg} / \mathrm{L}$ & $5.30 \pm 1.96$ & $5.44 \pm 1.78$ & $4.11 \pm 1.58$ & $4.63 \pm 1.64$ \\
\hline
\end{tabular}

*WT water temperature, EC electrical conductivity, TDS total dissolved solids, D.O. dissolved oxygen, Ca calcium, Mg magnesium , Mean values are of 24 observations

total number of macroinvertebrates counted are given in Table 3. Coleoptera was comprised of 6 generaAgabinus sp., Amphizoa sp., Hydaticus sp., Dineutus $s p$. Limnius $s p$. and Gyrinidae sp. The maximum number of Dineutus sp. was counted 38 ind. $/ \mathrm{m}^{2}$ at zone-A among all other species. Diptera comprised of 5 genera- Antocha sp., Chironomus sp., Culex sp., Simulium sp. and Phychoda sp. Antocha sp. was noted dominant at zone-B of the river. Ephemeroptera was found as a dominant group in this community. Ephemeroptera comprised of different 8 genera viz. Baetis sp., Cloeon sp., Emphemera sp., Ephemerella sp., Siphlonurus sp., Hydroptila sp., Heptagenia sp. and Leptophlebia sp. on all study zones. Hemiptera comprised 4 different genera: Gerris sp., Corexia sp., Hesperocorixa sp. and Aphelocheiridae sp. Gerris sp. was a maximum of 37 ind. $/ \mathrm{m}^{2}$ at zone-B. Odonta comprised of 4 different texa, namely Agrion sp., Hegenius sp., Ischnura sp. and Gomphidae sp., at sampling locations.

\section{Relationship between macroinvertebrates and environmental variables}

Water quality and substratum structure are very important for the benthic fauna community to sustain life in a water body. According to Allan and Castillo (2007), the river water level and flow are responsible for transferring nutrients in an ecosystem process. Benthic macroinvertebrates are disturbed by various anthropogenic activities. A few researchers have worked on the relationship status between abiotic and macroinvertebrates of a headwater stream in urban and rural water- sheds of Maryland (Smith and Lamp, 2008); (Koshal et al., 2017); (Burger et al., 2019); (Labuce et al., 2020) and (Ishaq and Khan, 2013). Silveira et al. (2006) noted riffles as the favourable substrate to macrobenthos in Macae Brazilian river. Belagali (2007) reported Coleoptera and Ephemeroptera species as pollution indicators in Mysore city lakes. A total number of 30 macrobenthos species have been reported by Jindal et al. (2020) in the Binwa Western Himalaya hill stream. Padmanabha. In present study, a total number of 27 macrobenthos communities belonging to 5 orders were recorded in the study zone of Alaknanda river. The two orders- Coleoptera and Ephemeroptera showed dominance in the river. Some previous studies showed the decline of water quality due to anthropogenic activities such as the discharge of sewage water (Aswal et al., 2016) and other activities such as tourism (Semwal and Mishra, 2019). However, in selected zones of the present study, the lowest number of macrobenthos was noted at zone- $C$ of the river. It may be due to the more water temperature $\left(17.34 \pm 4.16{ }^{\circ} \mathrm{C}\right)$ and the maximum sand percentage $(25 \pm 5 \%)$ that interfered with the number of the biotic community. At this zone of the river, an increasing rate of water temperature was also observed due to the electricity generation of the Srinagar hydropower dam that enhanced the water flow temperature in river water. The vast amount of water and its flow enhanced sedimentation as a major sandy habitat at this place. Though all physicochemical parameters of river water were under desirable limits of BIS/WHO, the species of Ephemeroptera were found in the dominant 
Tomar, G. et al. / J. Appl. \& Nat. Sci. 13(3), 1135 - 1142 (2021)

Table 3. Mean values of macrobenthos in different zones of river Alaknanda during 2016-2018

\begin{tabular}{|c|c|c|c|c|c|}
\hline S. No. & $\begin{array}{l}\text { Species }\left(\operatorname{Ind} / \mathrm{m}^{2}\right) \\
\text { Coleoptera }\end{array}$ & $\begin{array}{l}\text { Zone A } \\
\text { Avg } \pm \text { S.D. }\end{array}$ & $\begin{array}{l}\text { Zone B } \\
\text { Avg士S.D. }\end{array}$ & $\begin{array}{l}\text { Zone C } \\
\text { Avg } \pm \text { S.D. }\end{array}$ & $\begin{array}{l}\text { Zone D } \\
\text { Avg士S.D. }\end{array}$ \\
\hline 1. & Agabinus sp. & $29 \pm 19$ & $19 \pm 15.29$ & $17 \pm 14$ & $24 \pm 21$ \\
\hline 2. & Amphizoa sp. & $33 \pm 25$ & $25 \pm 23$ & $19 \pm 18$ & $27 \pm 29$ \\
\hline 3. & Hydaticus sp. & $29 \pm 17$ & $28 \pm 27$ & $17 \pm 16$ & $23 \pm 28$ \\
\hline 4. & Dineutus sp. & $38 \pm 30$ & $34 \pm 33$ & $13 \pm 10$ & $28 \pm 26$ \\
\hline 5. & Limnius sp. & $18 \pm 14$ & $23 \pm 20$ & $9 \pm 7$ & $12 \pm 10$ \\
\hline \multirow[t]{2}{*}{6.} & Gyrinidae sp. & $14 \pm 10$ & $10 \pm 3$ & $4 \pm 2$ & $6 \pm 3$ \\
\hline & Diptera & & & & \\
\hline 1. & Antocha sp. & $43 \pm 25$ & $47 \pm 35$ & $23 \pm 21$ & $28 \pm 22$ \\
\hline 2. & Chironomus sp. & $27 \pm 16$ & $23 \pm 11$ & $11 \pm 7$ & $16 \pm 14$ \\
\hline 3. & Culex sp. & $18 \pm 14$ & $14 \pm 13$ & $8 \pm 6$ & $10 \pm 7$ \\
\hline 4. & Simulium sp. & $32 \pm 28$ & $36 \pm 30$ & $18 \pm 17$ & $24 \pm 20$ \\
\hline \multirow[t]{2}{*}{5.} & Phychoda sp. & $24 \pm 19$ & $29 \pm 27$ & $14 \pm 12$ & $21 \pm 16$ \\
\hline & Ephemeroptera & & & & \\
\hline 1. & Baetis sp. & $66 \pm 73$ & $73 \pm 47$ & $44 \pm 41$ & $44 \pm 40$ \\
\hline 2. & Cloeon sp. & $50 \pm 45$ & $55 \pm 62$ & $23 \pm 19$ & $27 \pm 32$ \\
\hline 3. & Emphemera sp. & $51 \pm 62$ & $51 \pm 48$ & $28 \pm 30$ & $34 \pm 29$ \\
\hline 4. & Ephemerella sp. & $42 \pm 50$ & $51 \pm 50$ & $23 \pm 21$ & $29 \pm 27$ \\
\hline 5. & Siphlonurus sp. & $30 \pm 27$ & $35 \pm 29$ & $17 \pm 27$ & $23 \pm 20$ \\
\hline 6. & Hydroptila sp. & $39 \pm 41$ & $24 \pm 18$ & $17 \pm 14$ & $30 \pm 28$ \\
\hline 7. & Heptagenia sp. & $31 \pm 29$ & $22 \pm 20$ & $9 \pm 7$ & $13 \pm 8$ \\
\hline \multirow[t]{2}{*}{8.} & Leptophlebia sp. & $14 \pm 8$ & $19 \pm 15$ & $21 \pm 19$ & $7 \pm 4$ \\
\hline & Hemiptera & & & & \\
\hline 1. & Gerris sp. & $33 \pm 25$ & $37 \pm 33$ & $25 \pm 22$ & $21 \pm 19$ \\
\hline 2. & Corexia sp. & $12 \pm 7$ & $15 \pm 13$ & $7 \pm 6$ & $9 \pm 4$ \\
\hline 3. & Hesperocorixa sp. & $21 \pm 15$ & $19 \pm 11$ & $9 \pm 5$ & $13 \pm 9$ \\
\hline \multirow[t]{2}{*}{4} & Aphelocheiridae sp. & $12 \pm 5$ & $18 \pm 9$ & $19 \pm 22$ & $8 \pm 5$ \\
\hline & Odonata & & & & \\
\hline 1. & Agrion sp. & $16 \pm 10$ & $22 \pm 12$ & $11 \pm 9$ & $9 \pm 3$ \\
\hline 2. & Hegenius sp. & $30 \pm 22$ & $26 \pm 25$ & $18 \pm 17$ & $17 \pm 13$ \\
\hline 3. & Ischnura sp. & $19 \pm 27$ & $23 \pm 22$ & $9 \pm 6$ & $12 \pm 15$ \\
\hline 4. & Gomphidae sp & $14 \pm 9$ & $19 \pm 17$ & $25 \pm 22$ & $7 \pm 5$ \\
\hline
\end{tabular}

*Zone A-Chamoli to Nanadprayag, Zone B- Karanprayag to Rudraprayag, Zone C- Dharidevi to Srinagar,Zone D- Chauras to Devprayag ; Mean values are of 24 observations

number at zone-C with some pollution indicator species (Cloeon sp., Emphemera sp. and Bateis sp.). The slight river water pollution was due to direct inlet of waste and human interference such as clothes washing, bathing, and construction activities on river bank stretches.

\section{Biodiversity indices status of river Alaknanda}

Variation in different biodiversity indices of macroinvertebrates in different regions based on the availability of essential resources for the biota in their habitat is given in Table 4. The values of the Dominance index were found to be highest 0.0382 at zone-D and lowest
0.0370 at zone-C. The values of Shannon index were observed as highest 3.3890 at zone-C and lowest 3.3700 recorded at zone-D. Kumari and Maiti, (2020) also found Shannon's value in the range of 2.46-3.15, and Simpson's value of 0.86-0.95 was for macroinvertebrates in Jamshedpur city microalgal freshwater bodies. Matin et al. (2018) and Hossain et al. (2013) observed Shannon index values ranging from a minimum of 2.24 to a maximum of 2.97. In the present study, the evenness value was observed highest to be 0.8979 at zone-C, and the lowest value of 0.8809 was found at zone-D. The values of Brillouin index were lowest as 3.2490 at zone-D, and the highest 3.3000 was at zone- 
Tomar, G. et al. / J. Appl. \& Nat. Sci. 13(3), 1135 - 1142 (2021)

Table 4. Variations in diversity indices of macrobenthos in different zones of river Alaknanda during 2016-2018

\begin{tabular}{|c|c|c|c|c|}
\hline Biodiversity indices & Zone A & Zone B & Zone C & Zone D \\
\hline Taxa_S & 33.000 & 33.000 & 33.000 & 33.000 \\
\hline Individuals & 890.00 & 910.00 & 565.00 & 598.00 \\
\hline Dominance_D & 0.0376 & 0.0379 & 0.0370 & 0.0382 \\
\hline Simpson_1-D & 0.9624 & 0.9621 & 0.9630 & 0.9618 \\
\hline Shannon_H & 3.3820 & 3.3870 & 3.3890 & 3.3700 \\
\hline Evenness_e $\mathrm{e}^{\wedge} \mathrm{H} / \mathrm{S}$ & 0.8915 & 0.8966 & 0.8979 & 0.8809 \\
\hline Brillouin & 3.2930 & 3.3000 & 3.2630 & 3.2490 \\
\hline Menhinick & 1.1060 & 1.0940 & 1.3880 & 1.3490 \\
\hline Margalef & 4.7120 & 4.6970 & 5.0500 & 5.0050 \\
\hline Equitability_J & 0.9672 & 0.9688 & 0.9692 & 0.9637 \\
\hline Fisher_alpha & 6.7490 & 6.7110 & 7.6460 & 7.5190 \\
\hline Berger-Parker & 0.0742 & 0.0802 & 0.0779 & 0.0736 \\
\hline
\end{tabular}

*Zone A-Chamoli to Nanadprayag, Zone B- Karanprayag to Rudraprayag, Zone C- Dharidevi to Srinagar,Zone D- Chauras to Devprayag

B. The largest value of 1.3880 Menhinick index was noted at zone-C, and the smallest 1.0940 was observed at zone-B. Margalef index was highest 5.0500 at zone-C, and the smallest values were recorded as 4.6970 at zone-B. Fisher alpha index values were 6.7490 at zone-A, 6.7110 at zone-B, 7.6460 at zone-C and 7.5190 at zone-D. Higher 0.0802 Berger-Parker index was reported at zone- $B$, and the lowest 0.0736 was found at zone-D during two years of study. The biodiversity indices values showed good to medium diversity at all sampling sites. The anthropogenic activities like the construction of steps leading down to the river at zone-A, $B$ and $D$, electricity generation by hydropower plant at zone-C; and road widening and tourism activities at all the zones interrupted the substrate structure of the aquatic habitat resulting in the variation of biodiversity with a biota loss at zone-C of the river.

\section{Conclusion}

The present study observed that all the nine water quality parameters viz. substratum, water temperature, water velocity, $\mathrm{pH}$, electrical conductivity, total dissolved solids, dissolved oxygen, $\mathrm{Ca}$ and $\mathrm{Mg}$ of the sampling zones at the river Alaknanda were under the permissible limit of BIS/WHO. The most favourable substrata to macrobenthos were pebbles and gravels at zone-A, B, C, and D that supported their good diversity in the river water. The number of macrobenthos at different river zones was in the order of zone-B> zone$A>$ zone-D> zone- $C$. The macrobenthic community was lowest in number at zone-C due to the SrinagarGarhwal hydropower project's interference of natural river flow. The maximum water velocity was at this zone which disturbed the habitat. Though the biodiversity indices values showed good to medium diversity at all sampling sites, anthropogenic activities resulted in the variation of biodiversity at different zones with a biota loss at zone- $\mathrm{C}$ of the river Alaknanda.

\section{ACKNOWLEDGEMENTS}

The author is gratefully acknowledged to the Department of Science and Technology, New Delhi, National Institute of Hydrology, Roorkee and Department of Zoology and Environmental Sciences, Gurukula Kangri (Deemed to be University), Haridwar for their support to this research work.

\section{Conflict of interest}

The authors declare that they have no conflict of interest.

\section{REFERENCES}

1. Allan, J.D. \& Castillo, M.M. (2007). Stream Ecology: Structure and function of running waters. Netherlands, Springer, Pp: 436.

2. American Public Health Association (2012). Standard methods for the examination of water and wasteland. $22^{\text {th }}$ edition. Am. Public health Assoc. Washington, D.C. Pp: 1534.

3. Arimoro, F.O., Abubakar, M.D., Obi-lyeke, G.E. \& Keke, U.N. (2020). Achieving sustainable river water quality for rural dwellers by prioritizing the conservation of macroinvertebrates biodiversity in two Afrotropical streams. Environmental and Sustainability Indicators, 10: 100103. doi.org/10.1016/j.indic.2021.100103.

4. Aswal, R.S., Singh, P., Kamboj, N. \& Singh, R. (2016). Chemometric techniques: a comparative study of drinking 
water sources of Dehradun and Haridwar, Uttarakhand (India). Advances in Health and Environment, Safety Select Proceedings of HSFEA, 345-352.

5. Aazami, J., KianiMehr, N. \& Abasali, Z. (2019). Ecological water health assessment using benthic macroinvertebrate communities (case study: the Ghezel Ozan River in Zanjan Province, Iran) Environ Monit Assess, 191, 689 https:// doi.org/10.1007/s10661-019-7894-1.

6. Balodi, V.P. \& Koshal, K. (2015). Macro- Zoobenthic study in relation to physico- Chemical parameters of Khoh River in Uttarakhand. Int. J. Sci. Res. 4 (6), 171-173.

7. Burger, M., Vuren, V.J.H., Wet, L.D. \& Nel, A. (2019). A comparison of water quality and macroinvertebrate community structure in endorheic depression wetlands and a salt Gauteng province, South Africa. Environmental Monitoring Assessment, 191-14.

8. Day, S.M. (1979). Teaching and research in limnology in India, In, Proceedings of the symposium UGC NCSE, Bangalore, Pp: 67-72.

9. Duka, S., Bledar, P., Erjola, K., Anila, P. \& Pranvera, L. (2017). Biomonitoring of water quality of the Osumi, Devolli, and Shkumbini rivers through benthic macroinvertebrates and chemical parameters. Journal of Environmental Science and Health, 52(5), 471-178, http://dx.doi.org/1 $0.1080 / 10934529.2016 .1274167$.

10. Edmondson, W.T. (1957). Trophic relation of the zooplankton. Trans. Am. Microse. Soc., 76, 225-246.

11. Elias, J.D., ljumba, J.N., Mgay, Y.D. \& Mamboya, F.A. (2014). Study on Freshwater Macroinvertebrates of Some Tanzanian Rivers as a Basis for Developing Biomonitoring Index for Assessing Pollution in Tropical African Regions. Hindawi Publishing Corporation Journal of Ecosystems, http://dx.doi.org/10.1155/2014/985389.

12. Ganguly, S., Patnaik, L. \& Nayak, S. (2018). Macroinvertebrates and its impact in assessing water quality of riverine system: A case study of Mahanadi river, Cuttack, India. Journal of Applied and Natural Science, 10(3), 958963.

13. Hellawell, J.M. (1977). Change in natural and managed ecosystems. detection, measurement and assessment. Proc. R. Soc. London. B, 197, 31-57.

14. Hossain, M.B., Amin, S.M.N., Asadujjaman, M. \& Rahman, S. (2013). Analyzes of Macrobenthos of Hatiya and NijhumDweep Islands at higher Taxonomic Resolution. $J$. Fish. Aquat. Sci., 8 (4), 526-534.

15. Ishaq, F. \& Khan, A. (2013). Seasonal limnological variation and macro benthic diversity of river Yamuna at Kalsi Dehradun of Uttarakhand. Pelagia Research, 3(2), 133144.

16. Jindal, R., Singh, D. \& Chandel, V.C. (2020). Checklist of macroinvertebrates of Binwa a western Himalayan hill stream and their role as bioindicator. Plant Archives, 20 (1), 2674-2677.

17. Johnson, C.N., Andrew, B., Barry, W.B., Jessie, C.B., Mauro, G., \& Janet, M.W. (2017). Biodiversity losses and conservation responses in the Anthropocene. Science, 356, 256-274.

18. Kamboj, V. \& Kamoj, N. (2020). Spatial and temporal variation of zooplankton assemblage in the mining-impacted stretch of Ganga River, Uttarakhand, India. Environmental Science and Pollution Research, 1-12.

19. Koshal, K., Rana, J.S., Rana, R.A. \& Kotnala, C.B. (2017)
Checklist of benthic macroinvertebrate communities of stream Rawasan in Garhwal region (Central Himalayas, Uttarakhand, India. Journal Mountain Research, 12, 91-95.

20. Kumar, N., Kumar, B. \& Dobriyal, A.K. (1998). Geomorphic influence on the distribution of benthic diversity in two hill streams of Garhwal Himalaya. Proceedings of IndoUs Workshop. Punjab University Chandigarh. Pp: 53-66.

21. Kumar, K., Rana, J.S., Rawat, A. \& Kotnala, B.C. (2017). Checklist of benthic macroinvertebrate communities of stream Rawasan in Garhwal region (Central Himalaya), Uttarakhand (India). Journal Mountain Research, 12, 91-95.

22. Kumari, P. \& Maiti, S.K. (2020). Bioassessment in the aquatic ecosystems of highly urbanized agglomeration in India: An application of physicochemical and macroinvertebrate-based indices. Ecological Indicators, 111: 106053.

23. Labuce, A., Inta, D., Tunens, J. \& Strake, S. (2020). Zooplankton indicator based assessment in relation to site location and abiotic factors: A case study from the Gulf of Riga. Environmental Monitoring Assessment, 192-147.

24. Malik, D.S., Sharma, A.K. \& Sharma, A.K. (2020). Current Status of Microbenthic Diversity And their Habitat Ecology in River Ganga and its Tributaries, Uttarakhand. Journal of Experimental Zoology, India, 23(2), 1413-1420.

25. Matin, A., Hossain, B.M., Iqbal, M., Billah, M.M., Asif, A. \& Billah, M.M. (2018). Diversity and abundance of macrobenthos in a Subtropical Estuary Bangladesh. Species, 19, 140-150.

26. Mishra, A., Mukherjee, A. \& Tripathi, B.D. (2009). Seasonal and temporal variations in physico-chemical and bacteriological characteristics of River Ganga in Varanasi. International Journal of Environmental Research, 3(3), 395-402.

27. Padmanabha, B. \& Belagali, S.L. (2007). Diversity indices of rotifers for the assessment of pollution in the lakes of Mysore city, India. Pollution Research, 26(1), 65-68.

28. Pajtim, B., Marton, C., Albona, S.A., Osman, F., Ismaili, M. \& Mimoza, H. (2019). Macrophytes as biological indicators of organc pollution in the lepenci river basin in Kosovo. Journal of Freshwater Ecology, 35(1): 105-121, DOI: 10.1080/02705060.2020.1745913.

29. Pennak, R.W. (1953). Comparative limnology of eight Colorado mountain lakes, Univ. Colo. Studies. Ser. Biol., 2, 1-75.

30. Rana, J.S., Semalty, B., Singh, P., Swami, N., Dewan, S., Singh, J., Gusain, M.P. \& Gusain, O.P. (2017). Checklist of benthic macroinvertebrate taxa along different riparian land use types in Alaknanda River Catchment of the Central Himalaya, Uttarakhand (India). Proc. Zool. Soc. 1-24.

31. Rosenzweig, M.L. (1995). Species diversity in space and time. Cambridge University Press, New York. pp. 80

32. Sabha, I., Khanday, S.A., Sheikh, T.I. \& Sami, U.B. (2020). Longitudinal and temporal assemblage patterns of benthic macroinvertebrates in snow melt stream waters of Jhelum river basin of Kashmir Himalaya, India. Ecohydrology, 13, 1-16 DOI: 10.1002/eco.2236.

33. Semwal, V.P. \& Mishra, A.S. (2019). The distributional pattern of benthic macro species in a spring-fed foothill tributary of the Ganga River, western Himalaya, India. Journal of Threatened Taxa, 11(12), 14511-14517.

34. Sharma, R.C. \& Rawat, J.S. (2009). Monitoring of aquatic macroinvertebrates as bioindicator for assessing the health of wetlands: A case study in the Central Himalayas, India. Ecological Indicators, 9, 118-128. 
35. Shannon, C.E. \& Wiener, W. (1949). The mathematical theory of communication. University of Illinois Press, Urbana Pp: 130.

36. Silveira, M.P., Buss, D.F., Nessimian, J.L. \& Baptista, D.F. (2006). Spatial and temporal distribution of benthic macrospecies in southeastern Brazilian river. Brazilian Journal of Biology 66(2), 623 - 632 DOI: 10.1590/s151969842006000400006 .

37. Simpson, G.H. (1949). Measurement of diversity. Nature, 163-688.

38. Singh, G.S., Rao, K.S. \& Saxena, K.G. (1998). Ecocultural analysis of sacred species and ecosystems in Chhakinal watershed, Himachal Pradesh. Conserving the sacred for biodiversity management. New Delhi, Kolkata: Oxford \& IBH publishing Co. Pvt. Ltd., Pp: 301-314.

39. Singh, J., Gusain, M.P. \& Gusain, O.P. (2010). Benthic insect-substratum relationship along an altitudinal gradient in Himalayan stream, India. Int. J. Ecol. Env. Sci. 36 (4),
215-231.

40. Singh, S. \& Sharma, R.C. (2020). Monitoring of benthic macro invertebrates as bio indicator for assessing the health of the highaltitude wetland Dodi Tal, Garhwal Himalaya, India. Biodiversity International Journal, 4(4), 164173 DOI: $10.15406 / \mathrm{bij} 2020.04 .00180$.

41. Singh, A.K. (1998) Abundance of microbenthic organisms in relation to the physico-chemical characteristics of river Ganga at Patna (Bihar), India. Journal of Environmental Biology, 18(2), 103-110.

42. Smith, R.F. \& Lamp, W.O. (2008). Comparison of insect communities between adjacent headwater and main-stem streams in urban and rural watersheds. Journal of North American Benthological Society 27,1: 161-175 DOI: 10.1899/07-071.1.

43. Wentworth, C.K. (1922). A scale of grade and class terms for clastic sediments. Published by the director of the United States Geological survey. pp- 371-392. 